ARTICLE

\title{
Enhanced hydrogen generation by reverse spillover effects over bicomponent catalysts
}

\author{
Zhe Gao 10 1,2凶, Guofu Wang ${ }^{1,2}$, Tingyu Lei (1) 1, Zhengxing Lv³, Mi Xiong ${ }^{1,2}$, Liancheng Wang ${ }^{1,2}$,
} Shuangfeng Xing ${ }^{1,2}$, Jingyuan $\mathrm{Ma}^{3}$, Zheng Jiang (1D ${ }^{3} \&$ Yong Qin (1D) $1,2 \times$

The contribution of the reverse spillover effect to hydrogen generation reactions is still controversial. Herein, the promotion functions for reverse spillover in the ammonia borane hydrolysis reaction are proven by constructing a spatially separated $\mathrm{NiO} / \mathrm{Al}_{2} \mathrm{O}_{3} / \mathrm{Pt}$ bicomponent catalyst via atomic layer deposition and performing in situ quick $\mathrm{X}$-ray absorption near-edge structure (XANES) characterization. For the $\mathrm{NiO} / \mathrm{Al}_{2} \mathrm{O}_{3} / \mathrm{Pt}$ catalyst, $\mathrm{NiO}$ and $\mathrm{Pt}$ nanoparticles are attached to the outer and inner surfaces of $\mathrm{Al}_{2} \mathrm{O}_{3}$ nanotubes, respectively. In situ XANES results reveal that for ammonia borane hydrolysis, the $\mathrm{H}$ species generated at $\mathrm{NiO}$ sites spill across the support to the Pt sites reversely. The reverse spillover effects account for enhanced $\mathrm{H}_{2}$ generation rates for $\mathrm{NiO} / \mathrm{Al}_{2} \mathrm{O}_{3} / \mathrm{Pt}$. For the $\mathrm{CoO}_{x} / \mathrm{Al}_{2} \mathrm{O}_{3} / \mathrm{Pt}$ and $\mathrm{NiO} / \mathrm{TiO}_{2} / \mathrm{Pt}$ catalysts, reverse spillover effects are also confirmed. We believe that an indepth understanding of the reverse effects will be helpful to clarify the catalytic mechanisms and provide a guide for designing highly efficient catalysts for hydrogen generation reactions.

\footnotetext{
${ }^{1}$ State Key Laboratory of Coal Conversion, Institute of Coal Chemistry, Chinese Academy of Sciences, Taiyuan 030001, China. ${ }^{2}$ Center of Materials Science and Optoelectronics Engineering, University of Chinese Academy of Sciences, Beijing 100049, China. ${ }^{3}$ Shanghai Synchrotron Radiation Facility, Shanghai Advanced Research Institute, Chinese Academy of Sciences, Shanghai 201204, China. ${ }^{凶}$ email: gaozhe@sxicc.ac.cn; qinyong@sxicc.ac.cn
} 
T he ever-increasing global energy demand and the detrimental effect of the $\mathrm{CO}_{2}$ product of fossil fuels have triggered a widespread search for alternative energy sources, which are effective and renewable and do not cause further environmental issues ${ }^{1}$. Because of its high energy density and renewability, $\mathrm{H}_{2}$ has been regarded as an attractive green fuel and a promising energy carrier for the future to meet increasing energy and environmental challenges ${ }^{2}$. Catalytic $\mathrm{H}_{2}$ generation from hydrogen storage materials is considered a potential method of $\mathrm{H}_{2}$ production if they can be effectively catalyzed ${ }^{3,4}$. The search for efficient catalytic systems would be greatly facilitated by a clearer understanding of the underlying chemical process.

Noble metal catalysts, such as $\mathrm{Pt}, \mathrm{Pd}$, and $\mathrm{Ru}$, have been recognized as important classes of catalysts for hydrogen generation, due to their high catalytic activity and durability ${ }^{5-11}$. It is noted that coupling metal catalysts with secondary metals ${ }^{12-15}$ and/or transition metal oxides ${ }^{16-25}$ is an encouraging strategy to further enhance catalytic performance. In the past, various theories (e.g., the metaloxide interfacial sites, electron interactions, or hydrogen reverse spillover effect) have been offered to explain the enhancement of $\mathrm{H}_{2}$ generation when different components are combined in a catalyst. For example, Francisco Zaera and coworkers argued that in the photocatalytic production of $\mathrm{H}_{2}$ from water with semiconductor catalysts, the role of metal additives is a reverse spillover effect, not to trap excited electrons ${ }^{26}$. Hydrogen reverse spillover, as a form of spillover, involves the migration of adsorbed hydrogen atoms from an oxide (or other nonmetal surface) to a metal, where they recombine to molecular hydrogen $27-29$. However, due to the lack of well-defined catalysts with clearly separated functional components and the difficulties in performing in situ characterization technologies, researchers have not formed an agreement on the enhancement mechanism. It is still a challenging issue to reveal the promotion effects of reverse spillover in $\mathrm{H}_{2}$ generation reactions.

In this work, taking the ammonia borane $\left(\mathrm{NH}_{3} \cdot \mathrm{BH}_{3}, \mathrm{AB}\right)$ hydrolysis reaction as an example, the promotion functions of reverse spillover in this reaction are proven using a spatially separated $\mathrm{NiO} / \mathrm{Al}_{2} \mathrm{O}_{3} / \mathrm{Pt}$ catalyst as a model catalyst, in combination with in situ quick XANES characterization. The $\mathrm{NiO} / \mathrm{Al}_{2} \mathrm{O}_{3} / \mathrm{Pt}$ catalyst was prepared by a facile and general template-assisted atomic layer deposition (ALD) method ${ }^{30-36}$. In situ XANES results clearly reveal that for $\mathrm{H}_{2}$ generation from $\mathrm{AB}$, the $\mathrm{H}$ species generated at $\mathrm{NiO}$ sites spill across the support to the $\mathrm{Pt}$ sites, i.e., reverse spillover phenomenon. This accounts for the enhanced $\mathrm{H}_{2}$ generation rates of bicomponent oxide-metal catalysts, compared with single component Pt-based catalysts. The reverse spillover effects are also confirmed for the $\mathrm{CoO}_{x} / \mathrm{Al}_{2} \mathrm{O}_{3} / \mathrm{Pt}$ and $\mathrm{NiO} / \mathrm{TiO}_{2} / \mathrm{Pt}$ catalysts. Our study provides a guide for designing highly efficient catalysts for hydrogen generation reactions.

\section{Results and discussion}

Synthesis and characterization of the catalysts. The $\mathrm{NiO} / \mathrm{Al}_{2} \mathrm{O}_{3} /$ Pt catalyst was synthesized by ALD using carbon nanocoils (CNCs) as templates (Supplementary Fig. 1). First, Pt nanoparticles (20 ALD cycles) and an $\mathrm{Al}_{2} \mathrm{O}_{3}$ film (50 ALD cycles) were deposited onto CNCs. The $\mathrm{CNC}$ templates were then removed by calcination. Finally, $\mathrm{NiO}$ nanoparticles (100 ALD cycles) were deposited, obtaining $\mathrm{NiO} / \mathrm{Al}_{2} \mathrm{O}_{3} / \mathrm{Pt}$. $\mathrm{Al}_{2} \mathrm{O}_{3} / \mathrm{Pt}$ and $\mathrm{NiO} / \mathrm{Al}_{2} \mathrm{O}_{3}$ were also produced as reference catalysts.

Figure 1a shows transmission electron microscopy (TEM) image of $\mathrm{NiO} / \mathrm{Al}_{2} \mathrm{O}_{3} / \mathrm{Pt}$. Hollow $\mathrm{Al}_{2} \mathrm{O}_{3}$ nanotubes with a uniform wall thickness $(\mathrm{ca} .7 \mathrm{~nm})$ can be clearly observed. The lattice distance of Pt nanoparticles was measured to be $\sim 0.226 \mathrm{~nm}$ (Supplementary Fig. 2), which corresponds to the $\mathrm{Pt}(111)$ plane. High-angle annular dark field scanning transmission electron microscopy (HAADF-STEM) image and energy-dispersive X-ray spectroscopy (EDX) mapping (Fig. 1d, e) for $\mathrm{NiO} / \mathrm{Al}_{2} \mathrm{O}_{3} / \mathrm{Pt}$ show that $\mathrm{Ni}$ and $\mathrm{Pt}$ are distributed on the outer and inner surfaces of $\mathrm{Al}_{2} \mathrm{O}_{3}$ nanotubes, respectively. The STEM image, EDX mapping, and line-scanning profile for a cross-sectional specimen prepared by focused ion beam milling along the vertical direction of the $\mathrm{Al}_{2} \mathrm{O}_{3}$ nanotubes (Supplementary Fig. 3) further demonstrate the separated structure of $\mathrm{NiO} / \mathrm{Al}_{2} \mathrm{O}_{3} / \mathrm{Pt}$. TEM images of the $\mathrm{Al}_{2} \mathrm{O}_{3} /$ $\mathrm{Pt}$ and $\mathrm{NiO} / \mathrm{Al}_{2} \mathrm{O}_{3}$ catalysts are shown in Fig. 1 b, c. There are no Pt particles on the outer surfaces of $\mathrm{Al}_{2} \mathrm{O}_{3}$ nanotubes for $\mathrm{Al}_{2} \mathrm{O}_{3} / \mathrm{Pt}$ (Supplementary Fig. 4). Due to the small size and low contrast of $\mathrm{NiO}$ nanoparticles, it is not straightforward to distinguish $\mathrm{NiO}$ nanoparticles in Fig. 1a, c. From the HRTEM image of $\mathrm{NiO} /$ $\mathrm{Al}_{2} \mathrm{O}_{3}$ (inset in Fig. 1c), $\mathrm{NiO}$ nanoparticles can be clearly observed. The Pt content in the catalysts was measured using inductively coupled plasma-atomic emission spectrometry (ICPAES) to be 3.65 and $4.23 \%$ for $\mathrm{NiO} / \mathrm{Al}_{2} \mathrm{O}_{3} / \mathrm{Pt}$ and $\mathrm{Al}_{2} \mathrm{O}_{3} / \mathrm{Pt}$, and the $\mathrm{Ni}$ content was measured to be 8.05 and $8.71 \%$ for $\mathrm{NiO} /$ $\mathrm{Al}_{2} \mathrm{O}_{3} / \mathrm{Pt}$ and $\mathrm{NiO} / \mathrm{Al}_{2} \mathrm{O}_{3}$, respectively. The $\mathrm{N}_{2}$ sorption isotherms for the $\mathrm{NiO} / \mathrm{Al}_{2} \mathrm{O}_{3}, \mathrm{Al}_{2} \mathrm{O}_{3} / \mathrm{Pt}$, and $\mathrm{NiO} / \mathrm{Al}_{2} \mathrm{O}_{3} / \mathrm{Pt}$ catalysts almost overlap (Fig. 1f). The Brunauer-Emmett-Teller (BET) surface areas for the $\mathrm{NiO} / \mathrm{Al}_{2} \mathrm{O}_{3}, \mathrm{Al}_{2} \mathrm{O}_{3} / \mathrm{Pt}$, and $\mathrm{NiO} / \mathrm{Al}_{2} \mathrm{O}_{3} / \mathrm{Pt}$ catalysts were calculated to be $95.4,93.6$, and $98.0 \mathrm{~m}^{2} \mathrm{~g}^{-1}$, respectively. Their pore volumes were $0.34,0.34$, and $0.39 \mathrm{~cm}^{3} \mathrm{~g}^{-1}$, respectively. The Barrett-Joiner-Halenda (BJH) pore size distribution curves (Fig. 1g) deduced from desorption branches of the $\mathrm{N}_{2}$ sorption isotherms confirm that $\mathrm{NiO} / \mathrm{Al}_{2} \mathrm{O}_{3}, \mathrm{Al}_{2} \mathrm{O}_{3} / \mathrm{Pt}$, and $\mathrm{NiO} / \mathrm{Al}_{2} \mathrm{O}_{3} / \mathrm{Pt}$ samples are made up of pores with average sizes centred at 54.9, 54.4, and $57.0 \mathrm{~nm}$, respectively. The pore sizes of these catalysts, i.e., the inner diameters of the $\mathrm{Al}_{2} \mathrm{O}_{3}$ nanotubes, correspond to the diameters of the $\mathrm{CNC}$ sacrificial templates. These results show that all the catalysts possess similar pore structures.

The X-ray photoelectron spectroscopy (XPS) results reveal the existence of $\mathrm{Ni}^{2+}$ species in $\mathrm{NiO} / \mathrm{Al}_{2} \mathrm{O}_{3}$ and $\mathrm{NiO} / \mathrm{Al}_{2} \mathrm{O}_{3} / \mathrm{Pt}$ (Fig. 1h). The XPS peaks for the two catalysts are similar. The XPS peaks located at binding energies of 856.1 and $874.0 \mathrm{eV}$ are attributed to Ni $2 p_{3 / 2}$ and $\mathrm{Ni} 2 p_{1 / 2}$, respectively, and the peaks located at binding energies of 861.8 and $879.7 \mathrm{eV}$ are attributed to satellite peaks. From the X-ray diffraction (XRD) patterns for the $\mathrm{Al}_{2} \mathrm{O}_{3} / \mathrm{Pt}$ and $\mathrm{NiO} / \mathrm{Al}_{2} \mathrm{O}_{3} / \mathrm{Pt}$ catalysts (Supplementary Fig. 5), the presence of Pt nanoparticles can be confirmed. No diffraction peak assigned to $\mathrm{NiO}$ is detected from the $\mathrm{XRD}$ patterns for $\mathrm{NiO} /$ $\mathrm{Al}_{2} \mathrm{O}_{3}$ and $\mathrm{NiO} / \mathrm{Al}_{2} \mathrm{O}_{3} / \mathrm{Pt}$, which can be ascribed to the high dispersion of ALD-prepared nanoparticles. Hydrogen temperature programmed reduction $\left(\mathrm{H}_{2}-\mathrm{TPR}\right)$ was used to study the redox properties of the catalysts (Fig. 1i). The profile obtained for $\mathrm{Al}_{2} \mathrm{O}_{3} / \mathrm{Pt}$ displays a principal reduction peak at $385^{\circ} \mathrm{C}$, which can be attributed to Pt interacting with $\mathrm{Al}_{2} \mathrm{O}_{3}{ }^{37}$. The $\mathrm{NiO} / \mathrm{Al}_{2} \mathrm{O}_{3}$ catalyst exhibits a small shoulder peak at approximately $349^{\circ} \mathrm{C}$ and a strong peak centred at $431^{\circ} \mathrm{C}$, corresponding to the reductions of bulk $\mathrm{NiO}$ and the $\mathrm{NiO}$ interacting with $\mathrm{Al}_{2} \mathrm{O}_{3}$. In contrast, for $\mathrm{NiO} / \mathrm{Al}_{2} \mathrm{O}_{3} / \mathrm{Pt}$, the first $\mathrm{H}_{2}$ consumption peak (corresponding to the reduction of bulk $\mathrm{NiO}$ ) shifts from 349 to $326^{\circ} \mathrm{C}$ and becomes obvious, and a broadened peak centred at $408^{\circ} \mathrm{C}$ (corresponding to the reductions of $\mathrm{Pt}$ and $\mathrm{NiO}$ interacting with $\mathrm{Al}_{2} \mathrm{O}_{3}$ ) can be observed. Quantification of the $\mathrm{H}_{2}$-TPR curves (Supplementary Table 1 ) shows that the hydrogen consumed by $\mathrm{NiO} / \mathrm{Al}_{2} \mathrm{O}_{3} / \mathrm{Pt}\left(1.86 \mathrm{mmol} \mathrm{H}_{2} \mathrm{~g}^{-1}\right)$ is greater than the sum of the hydrogen consumed by $\mathrm{Al}_{2} \mathrm{O}_{3} / \mathrm{Pt}(0.31 \mathrm{mmol} \mathrm{H}$ $\mathrm{g}^{-1}$ ) and $\mathrm{NiO} / \mathrm{Al}_{2} \mathrm{O}_{3}\left(1.29 \mathrm{mmol} \mathrm{H} \mathrm{g}^{-1}\right)$. These results demonstrate that the reduction of $\mathrm{NiO}$ species is promoted after $\mathrm{Pt}$ addition, which can be attributed to the hydrogen spillover effect $^{38-41}$. This hydrogen spillover effect is further confirmed from the results of in situ quick XANES experiments under a $\mathrm{H}_{2}$ atmosphere $\left(0.6 \mathrm{MPa}, 80^{\circ} \mathrm{C}\right.$ ) (Supplementary Figs. 6, 7 and Table 2). 

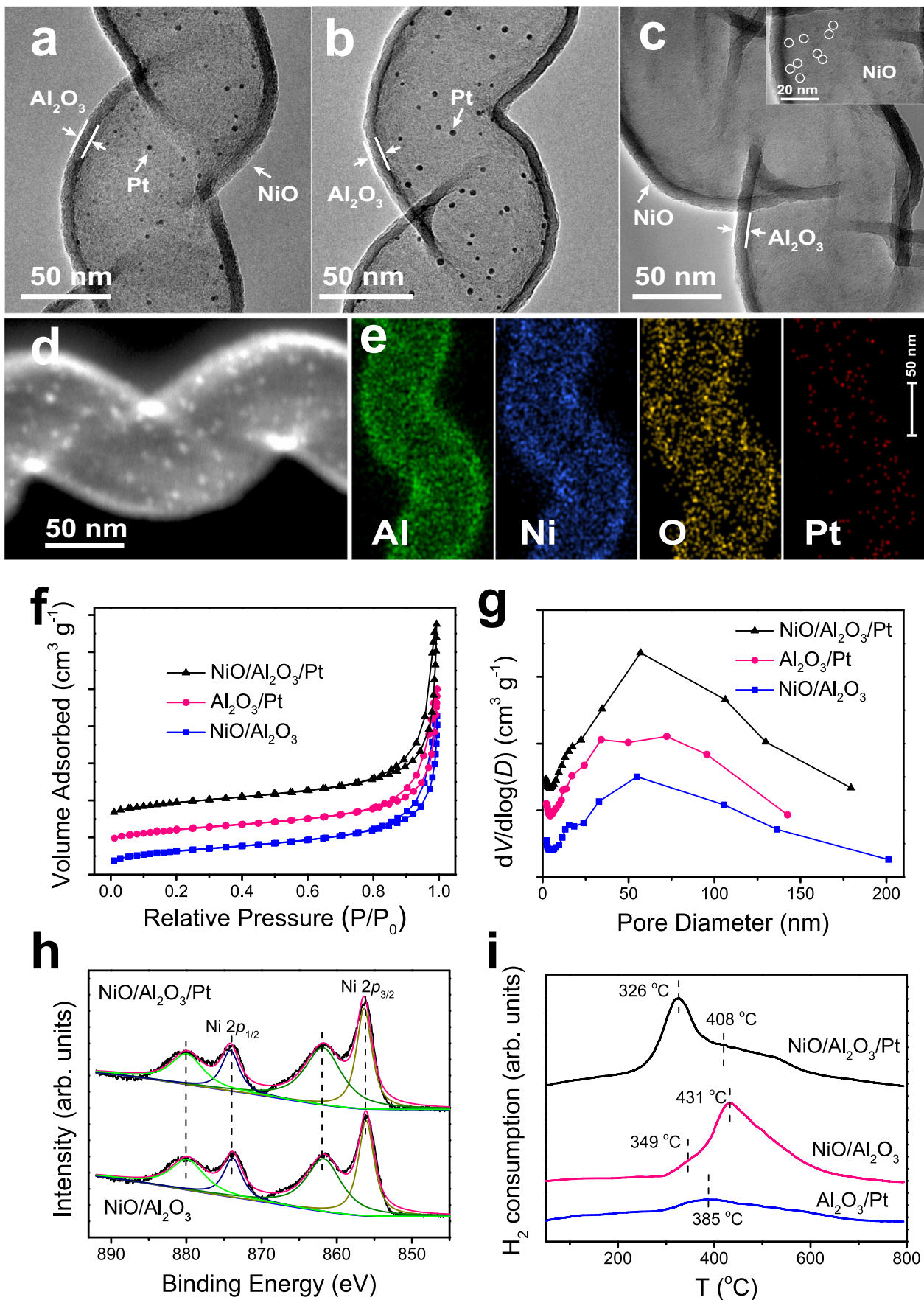

Fig. 1 Structure and chemisorption characterization of the catalysts. TEM images of a $\mathrm{NiO} / \mathrm{Al}_{2} \mathrm{O}_{3} / \mathrm{Pt}_{1} \mathbf{b} \mathrm{Al}_{2} \mathrm{O}_{3} / \mathrm{Pt}$, and $\mathbf{c} \mathrm{NiO} / \mathrm{Al} \mathrm{O}_{3}$ catalysts. Inset in c shows a HRTEM image of $\mathrm{NiO} / \mathrm{Al}_{2} \mathrm{O}_{3}$. d HAADF-STEM image and e EDX elemental mapping of the $\mathrm{NiO} / \mathrm{Al}_{2} \mathrm{O}_{3} / \mathrm{Pt}$ catalyst. $\mathbf{f} \mathrm{N}_{2}$ adsorption-desorption isotherms and $\mathbf{g}$ the corresponding pore size distributions of the catalysts. $\mathbf{h}$ XPS Ni $2 p$ analysis of $\mathrm{NiO} / \mathrm{Al}_{2} \mathrm{O}_{3}$ and $\mathrm{NiO} / \mathrm{Al}_{2} \mathrm{O}_{3} / \mathrm{Pt}$. $\mathbf{i} \mathrm{H}_{2}-\mathrm{TPR}$ profiles of NiO/ $\mathrm{Al}_{2} \mathrm{O}_{3}, \mathrm{Al}_{2} \mathrm{O}_{3} / \mathrm{Pt}$, and $\mathrm{NiO} / \mathrm{Al}_{2} \mathrm{O}_{3} / \mathrm{Pt}$.

Enhanced hydrogen generation after $\mathrm{NiO}$ addition. Here, the hydrolytic dehydrogenation of $\mathrm{AB}$ for $\mathrm{H}_{2}$ production is selected as a model reaction to investigate the reverse spillover effect. The catalytic performances of different catalysts for the dehydrogenation reaction of $\mathrm{AB}$ are shown in Fig. 2. A nearly linear $\mathrm{H}_{2}$ evolution curve is obtained for $\mathrm{Al}_{2} \mathrm{O}_{3} / \mathrm{Pt}$, suggesting a zero-order reaction with respect to $\mathrm{AB}$ (Fig. 2a). For the $\mathrm{NiO} / \mathrm{Al}_{2} \mathrm{O}_{3}$ catalyst, its $\mathrm{H}_{2}$ evolution curve exhibits a long induction period of approximately $20 \mathrm{~min}$, after which the curve starts to rise gradually. The $\mathrm{NiO}$ particles for $\mathrm{NiO} /$ $\mathrm{Al}_{2} \mathrm{O}_{3}$ are located on the outer surfaces of the $\mathrm{Al}_{2} \mathrm{O}_{3}$ nanotubes. The reactant molecules $\left(\mathrm{H}_{2} \mathrm{O}\right.$ and $\left.\mathrm{AB}\right)$ easily access the exposed $\mathrm{NiO}$ sites. Thus, the mass transfer in the porous structures is unlikely to lead to the induction period of the $\mathrm{NiO} / \mathrm{Al}_{2} \mathrm{O}_{3}$ catalyst. It is generally believed that new active species are generated during the induction period (Fig. 2b) ${ }^{42-44}$. However, even after reaction for $60 \mathrm{~min}$, the $\mathrm{H}_{2}$ evolution volume is still only $3.8 \mathrm{~mL}$, which shows an extremely poor activity for $\mathrm{NiO} / \mathrm{Al}_{2} \mathrm{O}_{3}$. For $\mathrm{NiO} / \mathrm{Al}_{2} \mathrm{O}_{3} / \mathrm{Pt}$, a rapid and linear $\mathrm{H}_{2}$ evolution curve without an induction period is obtained. The time required to complete the hydrolysis reaction for the $\mathrm{NiO}$ / $\mathrm{Al}_{2} \mathrm{O}_{3} / \mathrm{Pt}$ catalyst is less than that for $\mathrm{Al}_{2} \mathrm{O}_{3} / \mathrm{Pt}$, indicating that $\mathrm{NiO}$ addition can greatly enhance the activity of the $\mathrm{Al}_{2} \mathrm{O}_{3} / \mathrm{Pt}$ catalyst, even though $\mathrm{NiO}$ alone has little activity. 

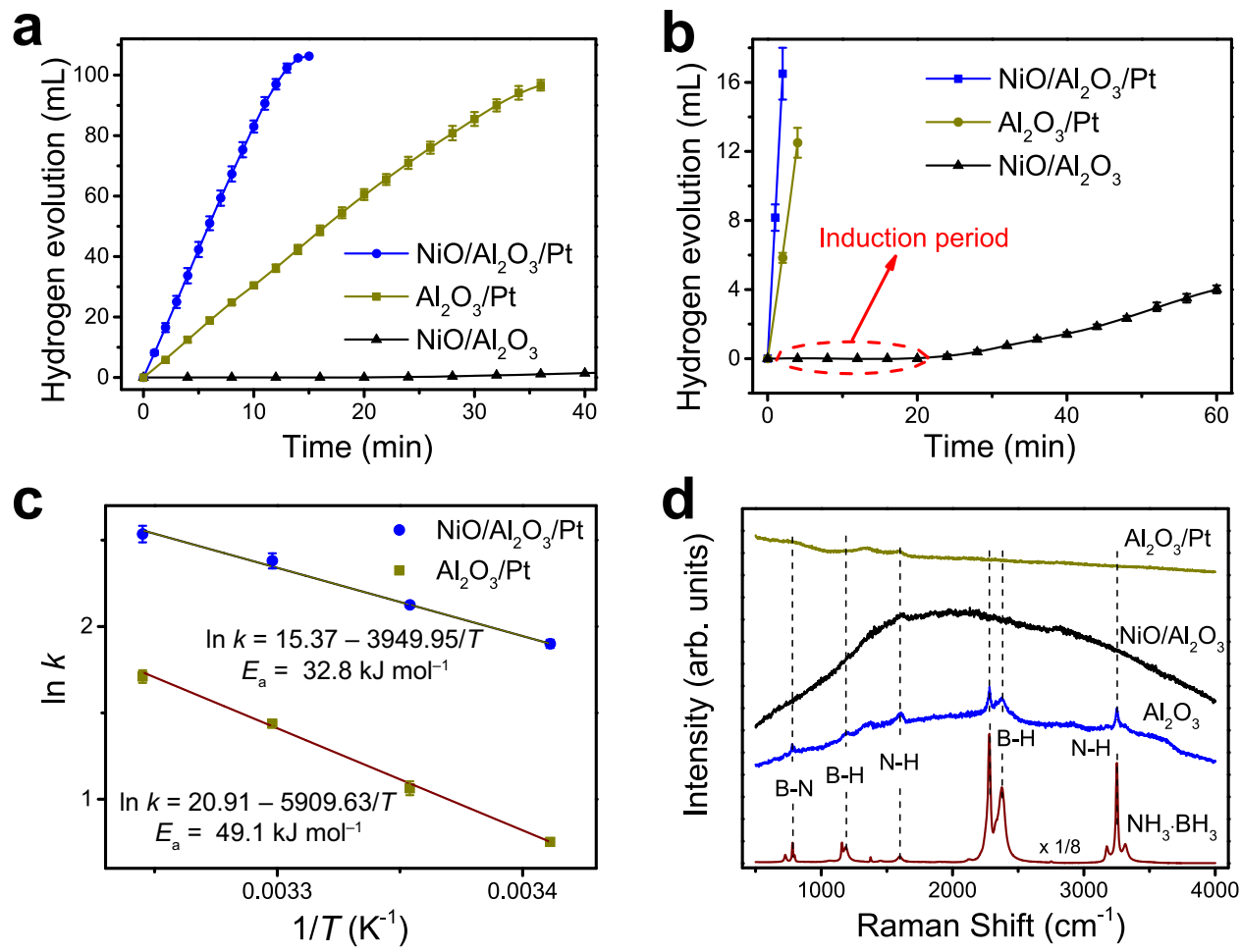

Fig. 2 Catalytic performances of catalysts for the dehydrogenation reaction of $\mathbf{A B}$ and Raman spectra for the used catalysts. a $\vee$ olume of $\mathrm{H}_{2}$ generated from $\mathrm{AB}$ solution $(0.15 \mathrm{~mol} \mathrm{~L}-1)$ at $25^{\circ} \mathrm{C}$ catalyzed by $\mathrm{NiO} / \mathrm{Al}_{2} \mathrm{O}_{3}, \mathrm{Al}_{2} \mathrm{O}_{3} / \mathrm{Pt}$, and $\mathrm{NiO} / \mathrm{Al}_{2} \mathrm{O}_{3} / \mathrm{Pt}$. $\mathbf{b}$ The volume of $\mathrm{H}_{2}$ generated at less than $18 \mathrm{~mL}$ versus prolonged time $\left(60 \mathrm{~min}\right.$ ) clearly shows the induction period for $\mathrm{NiO} / \mathrm{Al}_{2} \mathrm{O}_{3}$. c The Arrhenius plots for $\mathrm{Al}_{2} \mathrm{O}_{3} / \mathrm{Pt}$ and $\mathrm{NiO} / \mathrm{Al} \mathrm{I}_{3} / \mathrm{Pt}$. Error bars correspond to the standard deviation of three independent measurements. d Raman spectra for the used $\mathrm{Al}_{2} \mathrm{O}_{3}$ support, $\mathrm{NiO} / \mathrm{Al}_{2} \mathrm{O}_{3}$, and $\mathrm{Al}_{2} \mathrm{O}_{3} / \mathrm{Pt}$ after reaction for 10 min and data for the reference sample $\mathrm{NH}_{3} \cdot \mathrm{BH}_{3}$.

Kinetic experiments for the $\mathrm{Al}_{2} \mathrm{O}_{3} / \mathrm{Pt}$ and $\mathrm{NiO} / \mathrm{Al}_{2} \mathrm{O}_{3} / \mathrm{Pt}$ catalysts were also conducted. The time dependences for $\mathrm{H}_{2}$ generation at various temperatures $\left(20-35^{\circ} \mathrm{C}\right)$ were recorded (Supplementary Fig. 8). The catalysts still retain a linear increase in the $\mathrm{H}_{2}$ generation volume with reaction time. According to Arrhenius plots of $\ln k$ versus $1 / T$ (Fig. 2c), the activation energies $\left(E_{\mathrm{a}}\right)$ for the hydrolysis of $\mathrm{AB}$ using $\mathrm{Al}_{2} \mathrm{O}_{3} / \mathrm{Pt}$ and $\mathrm{NiO} / \mathrm{Al}_{2} \mathrm{O}_{3} / \mathrm{Pt}$ are calculated to be 49.1 and $32.8 \mathrm{~kJ} \mathrm{~mol}^{-1}$, respectively. The effect of the $\mathrm{AB}$ amount on the hydrolysis of $\mathrm{AB}$ was investigated (Supplementary Fig. 9). A nearly horizontal relationship in logarithmic plots between the $\mathrm{H}_{2}$ generation rate and $\mathrm{AB}$ concentration is further normalized, indicating that hydrolysis over $\mathrm{NiO} / \mathrm{Al}_{2} \mathrm{O}_{3} / \mathrm{Pt}$ is also a zero-order reaction with respect to the $\mathrm{AB}$ concentration.

The effects of the distance between $\mathrm{NiO}$ and $\mathrm{Pt}$ components (i.e., the thicknesses of the $\mathrm{Al}_{2} \mathrm{O}_{3}$ support) and $\mathrm{NiO}$ loadings in the catalyst on the catalytic performance were investigated (Supplementary Fig. 10). The synthesis procedures for $\mathrm{NiO} /$ $100 \mathrm{Al}_{2} \mathrm{O}_{3} / \mathrm{Pt}, \mathrm{NiO} / 200 \mathrm{Al}_{2} \mathrm{O}_{3} / \mathrm{Pt}$, and $50 \mathrm{NiO} / \mathrm{Al}_{2} \mathrm{O}_{3} / \mathrm{Pt}$ are similar to that for $\mathrm{NiO} / \mathrm{Al}_{2} \mathrm{O}_{3} / \mathrm{Pt}$, except for adjustment of the ALD cycles for the $\mathrm{Al}_{2} \mathrm{O}_{3}$ film and $\mathrm{NiO}$ nanoparticles (Supplementary Fig. 11). As expected, when the thickness of the $\mathrm{Al}_{2} \mathrm{O}_{3}$ support increases from $7 \mathrm{~nm}\left(\mathrm{NiO} / \mathrm{Al}_{2} \mathrm{O}_{3} / \mathrm{Pt}, 50\right.$ cycles of $\left.\mathrm{Al}_{2} \mathrm{O}_{3}\right)$ to $13 \mathrm{~nm}$ $\left(\mathrm{NiO} / 100 \mathrm{Al}_{2} \mathrm{O}_{3} / \mathrm{Pt}, 100\right.$ cycles of $\left.\mathrm{Al}_{2} \mathrm{O}_{3}\right)$ and $25 \mathrm{~nm}(\mathrm{NiO} /$ $200 \mathrm{Al}_{2} \mathrm{O}_{3} / \mathrm{Pt}, 200$ cycles of $\mathrm{Al}_{2} \mathrm{O}_{3}$ ), the catalytic activity decreases. As the $\mathrm{NiO}$ loading decreases, the $\mathrm{H}_{2}$ evolution rate also decreases. Even so, the activity of $\mathrm{NiO} / 100 \mathrm{Al}_{2} \mathrm{O}_{3} / \mathrm{Pt}, \mathrm{NiO} /$ $200 \mathrm{Al}_{2} \mathrm{O}_{3} / \mathrm{Pt}$, and $50 \mathrm{NiO} / \mathrm{Al}_{2} \mathrm{O}_{3} / \mathrm{Pt}$ is still higher than that of the single component $\mathrm{Al}_{2} \mathrm{O}_{3} / \mathrm{Pt}$ catalyst.

Catalytic mechanism. Raman measurements were employed to characterize the used catalysts after reaction for $10 \mathrm{~min}$, as shown in Fig. 2d. The Raman spectrum for the reference sample $A B$ shows the $B-N$ stretching mode at 727 and $783 \mathrm{~cm}^{-1}$, the $B-H$ stretching mode at 2280 and $2375 \mathrm{~cm}^{-1}$, the $\mathrm{N}-\mathrm{H}$ stretching mode at 3175,3251 , and $3316 \mathrm{~cm}^{-1}$, the $\mathrm{BH}_{3}$ deformation mode at 1159 and $1188 \mathrm{~cm}^{-1}$, and the $\mathrm{NH}_{3}$ deformation mode at 1600 $\mathrm{cm}^{-1}$, in agreement with the literature results ${ }^{45}$. For the $\mathrm{Al}_{2} \mathrm{O}_{3}$ support after reaction, these peaks can still be observed. For the $\mathrm{NiO} / \mathrm{Al}_{2} \mathrm{O}_{3}$ and $\mathrm{Al}_{2} \mathrm{O}_{3} / \mathrm{Pt}$ samples after reaction, the $\mathrm{NH}_{3}$ deformation peak can be found at approximately $1600 \mathrm{~cm}^{-1}$, while the $\mathrm{B}-\mathrm{N}$ and $\mathrm{B}-\mathrm{H}$ peaks cannot be observed. These results demonstrate that $\mathrm{NiO}$ and $\mathrm{Pt}$ can readily dissociate the $\mathrm{B}-\mathrm{N}$ and $\mathrm{B}-\mathrm{H}$ bonds of $\mathrm{AB}$ in the presence of $\mathrm{H}_{2} \mathrm{O}$.

The dynamic behaviour of $\mathrm{Ni}$ species in the catalysts under the $\mathrm{H}_{2}$ generation reaction was probed with a quick XANES. The incident X-rays usually produce no damage to the material, as opposed to the action of electron or ion probes ${ }^{46}$. This capability of XANES makes it suitable for (in situ) catalyst structure studies ${ }^{47}$. From Fig. 3a, it can be found that the intensity of the white line peak for $\mathrm{NiO} / \mathrm{Al}_{2} \mathrm{O}_{3}$ decreases with the reaction time, indicating that the $\mathrm{Ni}^{2+}$ species are gradually reduced. The $\mathrm{Ni}$ species are far from being fully reduced after reaction for $60 \mathrm{~min}$. Furthermore, the in situ XANES spectrum was simulated by a linear combination of the ex situ spectrum of the as-prepared catalyst and the spectrum for the reference sample (Ni foil) to quantitatively reveal the dynamic behaviour of $\mathrm{Ni}$ species in the catalysts during the reaction. The experimental XANES spectra can be reproduced perfectly by simple linear fitting, with an extremely low R factor (Supplementary Fig. 12 and Supplementary Table 3). The reduction degrees for $\mathrm{NiO} / \mathrm{Al}_{2} \mathrm{O}_{3}$ after reaction for $10,20,30,40,50$, and $60 \mathrm{~min}$ are $3.6 \pm 0.3,7.1 \pm 0.4,10.0 \pm 0.2$, $11.8 \pm 0.3,13.6 \pm 0.3$, and $14.2 \pm 0.2 \%$, respectively (Fig. $3 \mathrm{~b}$ ). The reduction degree does not increase linearly with reaction time. 

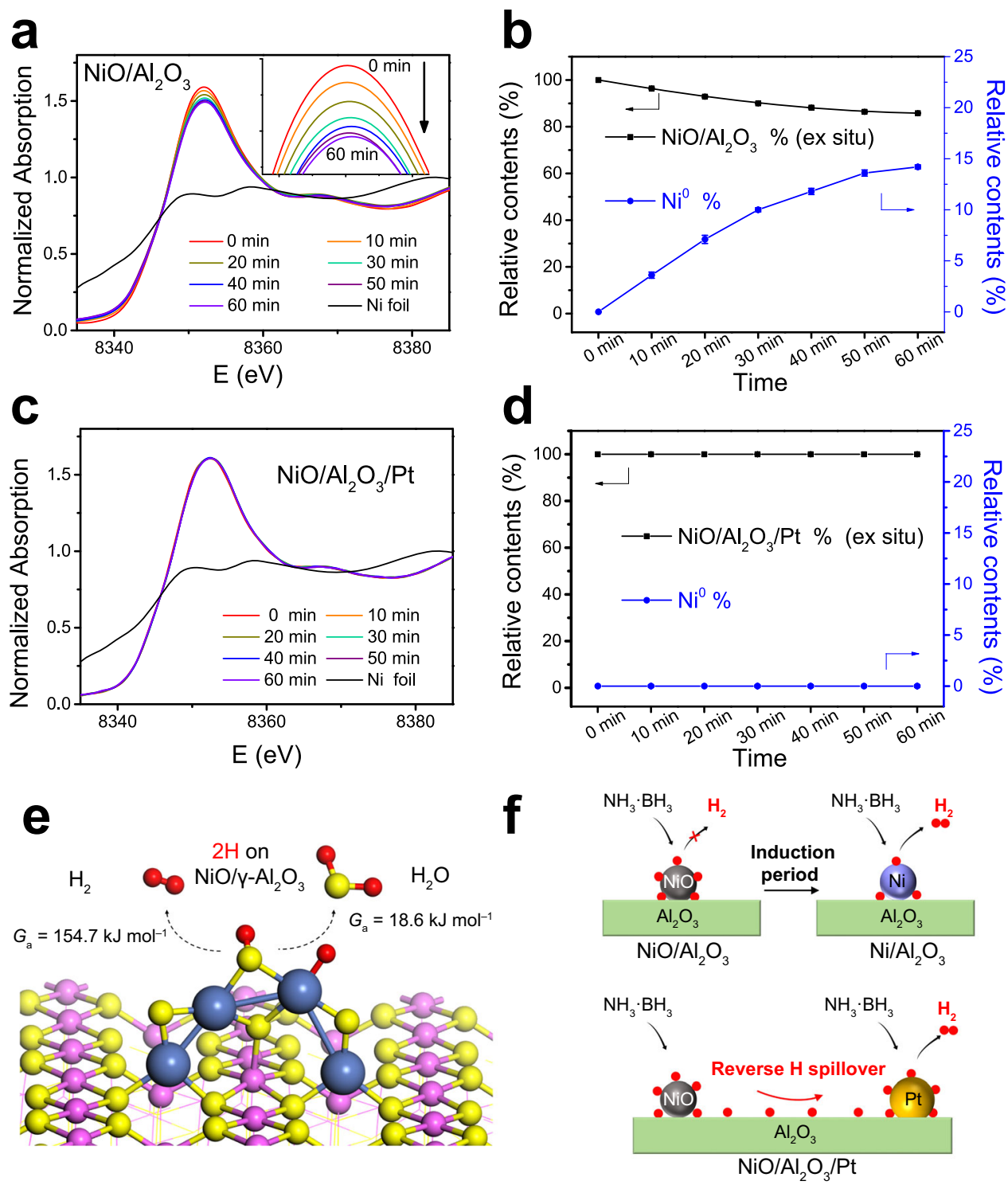

Fig. 3 In situ XANES spectra for the catalysts and proposed mechanisms. In situ Ni K-edge XANES spectra for a $\mathrm{NiO} / \mathrm{Al}_{2} \mathrm{O}_{3}$ and $\mathbf{c} \mathrm{NiO} / \mathrm{Al}_{2} \mathrm{O}_{3} / \mathrm{Pt}$, and the percent of metallic $\mathrm{Ni}^{O}$ in the $\mathbf{b} \mathrm{NiO} / \mathrm{Al}_{2} \mathrm{O}_{3}$ and $\mathbf{d} \mathrm{NiO} / \mathrm{Al}_{2} \mathrm{O}_{3} / \mathrm{Pt}$ catalysts versus time during the reaction. The inset in $\mathbf{a}$ shows the expanded sections for the white line peaks. For each sample, the in situ spectrum is fitted by a linear combination of the ex situ spectrum and the spectrum for Ni foil. Error bars represent the fitting errors from XANES. e The free energy barriers $\left(G_{a}\right)$ at room temperature $(298.15 \mathrm{~K})$ for the formation and desorption of $\mathrm{H}_{2}$ (left arrow) and water (right arrow) on $\mathrm{NiO} / \gamma-\mathrm{Al}_{2} \mathrm{O}_{3}(100)$ computed by the DFT method. Colour legend: $\mathrm{Al}$, pink; O, yellow; $\mathrm{Ni}$, cyan; and $\mathrm{H}$, red. $\mathbf{f}$ Proposed reaction mechanisms for $\mathrm{NiO} / \mathrm{Al}_{2} \mathrm{O}_{3}$ and $\mathrm{NiO} / \mathrm{Al}_{2} \mathrm{O}_{3} / \mathrm{Pt}$ in the $\mathrm{H}_{2}$ generation reaction. During the induction period for $\mathrm{NiO} / \mathrm{Al}_{2} \mathrm{O}_{3}$, the $\mathrm{H}$ species generated at $\mathrm{NiO}$ sites are consumed to reduce the oxide catalyst to metallic $\mathrm{Ni}{ }^{0}$. For $\mathrm{NiO} / \mathrm{Al}_{2} \mathrm{O}_{3} / \mathrm{Pt}$, the $\mathrm{H}$ species generated at $\mathrm{NiO}$ sites reversely spill across the $\mathrm{Al}{ }_{2} \mathrm{O}_{3}$ support to Pt sites, where they can combine into $\mathrm{H}_{2}$ and release.

These results demonstrate that metallic $\mathrm{Ni}^{0}$ species are generated gradually during the reaction, and the $\mathrm{Ni}^{0}$ generation rate slows down with time. For $\mathrm{NiO} / \mathrm{Al}_{2} \mathrm{O}_{3} / \mathrm{Pt}$, one may expect that more $\mathrm{NiO}$ will be reduced into metallic $\mathrm{Ni}^{0}$ after Pt addition due to spillover effects. Surprisingly, the in situ XANES spectra remain unchanged throughout the reaction, indicating that the reduction of $\mathrm{Ni}^{2+}$ species is totally inhibited after Pt addition (Fig. 3c, d).

\section{Discussion}

Our results show that the $\mathrm{H}_{2}$ generation rate for $\mathrm{Al}_{2} \mathrm{O}_{3} / \mathrm{Pt}$ for the hydrolysis of $\mathrm{AB}$ can be enhanced after $\mathrm{NiO}$ addition, even though $\mathrm{Pt}$ and $\mathrm{NiO}$ are spatially separated by $\mathrm{Al}_{2} \mathrm{O}_{3}$ support. Here, the promotion functions of reverse spillover in the $A B$ hydrolysis reaction are proven using a spatially separated catalyst as an ideal model catalyst based on kinetic analyses, Raman, in situ XANES, and DFT calculation results.

The $\mathrm{Al}_{2} \mathrm{O}_{3} / \mathrm{Pt}$ catalyst can catalyze the hydrolysis reaction of $\mathrm{AB}$ effectively, indicating that reactants can easily diffuse towards Pt sites. Pt nanoparticles for $\mathrm{Al}_{2} \mathrm{O}_{3} / \mathrm{Pt}$ are confined in the $\mathrm{Al}_{2} \mathrm{O}_{3}$ nanotubes. According to the $\mathrm{BJH}$ results, the average pore size of the nanotubes is larger than $50 \mathrm{~nm}$, which is the main channel for the diffusion of reaction molecules to Pt sites. The Raman results demonstrate that $\mathrm{Pt}$ can readily dissociate the $\mathrm{B}-\mathrm{N}$ and $\mathrm{B}-\mathrm{H}$ bonds for $\mathrm{AB}$ in the presence of $\mathrm{H}_{2} \mathrm{O}$, while the $\mathrm{Al}_{2} \mathrm{O}_{3}$ support cannot. Then, the generated $\mathrm{H}$ species are easily released from the Pt surface ${ }^{48}$.

The $\mathrm{NiO} / \mathrm{Al}_{2} \mathrm{O}_{3}$ catalyst shows poor activity in the hydrolysis reaction. However, the Raman results demonstrate that $\mathrm{NiO}$ can also dissociate the $\mathrm{B}-\mathrm{N}$ and $\mathrm{B}-\mathrm{H}$ bonds of $\mathrm{AB}$ in the presence of 
$\mathrm{H}_{2} \mathrm{O}$, generating $\mathrm{H}$ species. It is believed that $\mathrm{NiO}$ facilitates the adsorption of $\mathrm{H}-\mathrm{OH}$ and the dissociation of electropositive $\mathrm{H}$, which favours the attack of electronegative $\mathrm{H}$ in $\mathrm{AB}^{18}$. The $\mathrm{H}$ species generated at $\mathrm{NiO}$ sites can either be released as $\mathrm{H}_{2}$ from the oxide surface or can be consumed to reduce the $\mathrm{NiO}$ catalyst to metallic $\mathrm{Ni}^{0}$. The formation and desorption free energies for $\mathrm{H}_{2}$ and $\mathrm{H}_{2} \mathrm{O}$ on $\mathrm{NiO}$ sites in an aqueous environment were calculated using the DFT method (Fig. $3 \mathrm{e}$ and Supplementary Fig. 13). The free energy barrier $\left(G_{a}\right)$ at room temperature $(298.15 \mathrm{~K})$ for the formation of $\mathrm{H}_{2}$ is $154.7 \mathrm{~kJ} \mathrm{~mol}^{-1}$, whereas a much lower free energy barrier of $18.6 \mathrm{~kJ} \mathrm{~mol}^{-1}$ is required for $\mathrm{H}_{2} \mathrm{O}$ formation. This indicates that the $\mathrm{H}$ species tend to be consumed to reduce the $\mathrm{NiO}$ catalyst to form $\mathrm{H}_{2} \mathrm{O}$. At the induction period for the $\mathrm{H}_{2}$ evolution curve for $\mathrm{NiO} / \mathrm{Al}_{2} \mathrm{O}_{3}$, no $\mathrm{H}_{2}$ is produced, confirming that the $\mathrm{H}$ species are not released from the oxide surface. The in situ XANES results indicate that the generated $\mathrm{H}$ species are consumed for slowly reducing the oxide catalyst to metallic $\mathrm{Ni}^{0}$, which is consistent with the DFT results. After metallic $\mathrm{Ni}^{0}$ is produced, then the generated $\mathrm{H}$ species can be released from the metal surface (Fig. $3 \mathrm{f}$ ).

For the spatially separated $\mathrm{NiO} / \mathrm{Al}_{2} \mathrm{O}_{3} / \mathrm{Pt}$ catalyst, its $\mathrm{H}_{2}$ generation rate for the hydrolysis of $\mathrm{AB}$ is enhanced. The in situ XANES results indicate that no metallic $\mathrm{Ni}^{0}$ is observed in the $\mathrm{NiO} / \mathrm{Al}_{2} \mathrm{O}_{3} / \mathrm{Pt}$ catalyst during the $\mathrm{AB}$ hydrolysis reaction, while reduction is observed in the $\mathrm{NiO} / \mathrm{Al}_{2} \mathrm{O}_{3}$ catalyst. For both $\mathrm{NiO} / \mathrm{Al}_{2} \mathrm{O}_{3}$ and $\mathrm{NiO}$ / $\mathrm{Al}_{2} \mathrm{O}_{3} / \mathrm{Pt}$, NiO particles are located on the outer surfaces of $\mathrm{Al}_{2} \mathrm{O}_{3}$ nanotubes. $\mathrm{N}_{2}$ sorption isotherm results show that these two samples possess similar pore structures. Thus, the different reduction behaviours of $\mathrm{NiO}$ species for $\mathrm{NiO} / \mathrm{Al}_{2} \mathrm{O}_{3}$ and $\mathrm{NiO} / \mathrm{Al}_{2} \mathrm{O}_{3} / \mathrm{Pt}$ during the $\mathrm{AB}$ hydrolysis reactions are unlikely to be due to the mass transfer in the porous structures. The Raman results demonstrate that $\mathrm{H}$ species are generated at $\mathrm{NiO}$ and $\mathrm{Pt}$ sites at the same time. The $\mathrm{H}$ species generated at $\mathrm{NiO}$ sites can be released as $\mathrm{H}_{2}$ from the $\mathrm{NiO}$ surface, consumed to reduce $\mathrm{NiO}$, or released from $\mathrm{Pt}$ sites through reverse spillover. Generally, the desorption of $\mathrm{H}_{2}$ molecules on Pt sites is quite easy and is considered to be barrier free ${ }^{49,50}$. Thus, reverse spillover is the lowest energy pathway. This is also confirmed experimentally. The $\mathrm{H}_{2}$ evolution curve for $\mathrm{NiO} / \mathrm{Al}_{2} \mathrm{O}_{3}$ confirms that the $\mathrm{H}$ species are not released from $\mathrm{NiO}$. The reduction of $\mathrm{NiO}$ is totally inhibited after $\mathrm{Pt}$ addition, revealing that the $\mathrm{H}$ species generated at $\mathrm{NiO}$ sites are not consumed for the reduction of $\mathrm{NiO}$. The $\mathrm{H}$ species spill across the $\mathrm{Al}_{2} \mathrm{O}_{3}$ support from $\mathrm{NiO}$ to $\mathrm{Pt}$ sites, where they can combine into $\mathrm{H}_{2}$ and release (Fig. 3f). This is called the reverse spillover process, which accounts for the enhanced $\mathrm{H}_{2}$ generation rate for $\mathrm{NiO} / \mathrm{Al}_{2} \mathrm{O}_{3} / \mathrm{Pt}$ after $\mathrm{NiO}$ addition.

The reverse spillover phenomenon has also been confirmed in other catalytic systems, for example, in $\mathrm{AB}$ hydrolysis catalyzed by $\mathrm{CoO}_{x} / \mathrm{Al}_{2} \mathrm{O}_{3} / \mathrm{Pt}$. As shown in Fig. 4 a, an induction period can also be found in the $\mathrm{H}_{2}$ evolution curve for the $\mathrm{CoO}_{x} / \mathrm{Al}_{2} \mathrm{O}_{3}$ catalyst. For $\mathrm{CoO}_{x} / \mathrm{Al}_{2} \mathrm{O}_{3} / \mathrm{Pt}$, a rapid and nearly linear $\mathrm{H}_{2}$ evolution curve is obtained, and its activity is higher than that of $\mathrm{Al}_{2} \mathrm{O}_{3} / \mathrm{Pt}$. From the in situ XANES results, it can be found that after reaction for $30 \mathrm{~min}$, the position of the white line peak for $\mathrm{CoO}_{x} / \mathrm{Al}_{2} \mathrm{O}_{3}$ shifts to a lower energy, and the intensity of the white line peak decreases, indicating that the Co oxide species are reduced (Fig. 4b). For $\mathrm{CoO}_{x} / \mathrm{Al}_{2} \mathrm{O}_{3} / \mathrm{Pt}$, the change in the white line peak after the reaction is very slight (Fig. 4c). The in situ XANES spectrum was simulated by a linear combination of the ex situ spectrum for the as-prepared catalyst and the spectra obtained for the reference samples ( $\mathrm{CoO}$ and metallic $\left.\mathrm{Co}^{0}\right)$ (Supplementary Fig. 14). For $\mathrm{CoO}_{x} / \mathrm{Al}_{2} \mathrm{O}_{3}$ after reaction for 30 min, $9.9 \%$ extra $\mathrm{CoO}$ and $12.9 \%$ extra metallic $\mathrm{Co}^{0}$ are formed. However, for $\mathrm{CoO}_{x} / \mathrm{Al}_{2} \mathrm{O}_{3} / \mathrm{Pt}, 9.7 \%$ of extra $\mathrm{CoO}$ and only $1.6 \%$ of extra metallic $\mathrm{Co}^{0}$ are formed. It can be concluded that the reduction of Co oxide species to metallic $\mathrm{Co}^{0}$ is mostly inhibited after Pt addition.

In addition to nonreducible $\mathrm{Al}_{2} \mathrm{O}_{3}$, when reducible $\mathrm{TiO}_{2}$ is used as a support, reverse spillover effects are also confirmed (Supplementary Figs. 15 and 16). As shown in Fig. 4d, the induction period in the $\mathrm{H}_{2}$ evolution curve for the $\mathrm{NiO} / \mathrm{TiO}_{2}$ catalyst is shortened to $7 \mathrm{~min}$, indicating that $\mathrm{NiO}$ supported on $\mathrm{TiO}_{2}$ is easier to reduce than that supported on $\mathrm{Al}_{2} \mathrm{O}_{3}$. The $\mathrm{H}_{2}$ evolution curve for $\mathrm{NiO} / \mathrm{TiO}_{2} / \mathrm{Pt}$ is not linear. In the beginning, its rate is similar to that of $\mathrm{TiO}_{2} / \mathrm{Pt}$. After that, the rate for $\mathrm{NiO} /$ $\mathrm{TiO}_{2} / \mathrm{Pt}$ begins to increase rapidly, exceeding the rate for $\mathrm{TiO}_{2} / \mathrm{Pt}$. This implies that $\mathrm{NiO}$ sites are reduced to metallic $\mathrm{Ni}^{0}$ sites during the reaction. The in situ XANES spectra for $\mathrm{NiO} / \mathrm{TiO}_{2}$ and $\mathrm{NiO} / \mathrm{TiO}_{2} / \mathrm{Pt}$ are slightly rough, which is due to the high activities of the catalysts. The liquid reaction system is disturbed by a large amount of $\mathrm{H}_{2}$ bubbles, and thus, the X-ray absorption is affected. The in situ XANES (Fig. 4e, f) and its linear combination fitting results (Supplementary Fig. 17) demonstrate that for $\mathrm{NiO} / \mathrm{TiO}_{2}$ after reaction for $30 \mathrm{~min}, 26.1 \%$ extra metallic $\mathrm{Ni}^{0}$ is formed, while for $\mathrm{NiO} / \mathrm{TiO}_{2} / \mathrm{Pt}, 13.0 \%$ extra metallic $\mathrm{Ni}^{0}$ is formed. The reduction of $\mathrm{NiO}$ to metallic $\mathrm{Ni}^{0}$ is partially inhibited after $\mathrm{Pt}$ addition because of the reverse spillover effects. There are two competing pathways for the $\mathrm{H}$ species generated at the $\mathrm{NiO}$ sites of $\mathrm{NiO} / \mathrm{TiO}_{2} / \mathrm{Pt}$. A fraction of the $\mathrm{H}$ species spill over reversely to Pt sites; the rest is consumed to reduce $\mathrm{NiO}$ to metallic $\mathrm{Ni}^{0}$.

In summary, we designed spatially separated $\mathrm{NiO} / \mathrm{Al}_{2} \mathrm{O}_{3} / \mathrm{Pt}$ catalysts to clarify the contribution of the reverse spillover effect to enhanced $\mathrm{H}_{2}$ generation rates. The in situ XANES results reveal that the $\mathrm{H}$ species generated at $\mathrm{NiO}$ sites are not consumed for the reduction of $\mathrm{NiO}$ to $\mathrm{Ni}^{0}$ or released as $\mathrm{H}_{2}$ at $\mathrm{NiO}$ sites. Instead, they reversely spill across the support to the Pt sites. The reverse spillover effects account for the enhanced $\mathrm{H}_{2}$ generation rates. The effects are also confirmed for $\mathrm{CoO}_{x} / \mathrm{Al}_{2} \mathrm{O}_{3} / \mathrm{Pt}$ and $\mathrm{NiO} /$ $\mathrm{TiO}_{2} / \mathrm{Pt}$ catalysts. In general, we believe that, with the help of an in-depth understanding of reverse spillover effects, this work can provide guidance for rationally designing highly efficient catalysts for $\mathrm{H}_{2}$ production in the future.

\section{Methods}

Synthesis of $\mathbf{A l}_{\mathbf{2}} \mathbf{O}_{\mathbf{3}} / \mathbf{P t}$ catalysts. Typically, Pt nanoparticles (20 cycles) were deposited onto the CNC templates by ALD. Subsequently, the as-prepared Pt/ $\mathrm{CNCs}$ were coated by an $\mathrm{Al}_{2} \mathrm{O}_{3}$ support film (50 cycles). Then, the $\mathrm{CNC}$ templates were removed by calcination at $500^{\circ} \mathrm{C}$ for $1 \mathrm{~h}$, obtaining an $\mathrm{Al}_{2} \mathrm{O}_{3} / \mathrm{Pt}$ catalyst.

Synthesis of $\mathbf{N i O} / \mathrm{Al}_{2} \mathrm{O}_{3} / \mathrm{Pt}$ and $\mathrm{CoO}_{\mathbf{x}} / \mathbf{A l}_{\mathbf{2}} \mathbf{O}_{3} / \mathrm{Pt}$ catalysts. To obtain $\mathrm{NiO} /$ $\mathrm{Al}_{2} \mathrm{O}_{3} / \mathrm{Pt}$, NiO nanoparticles (100 cycles) were deposited onto $\mathrm{Al}_{2} \mathrm{O}_{3} / \mathrm{Pt}$ by ALD. The deposition cycles for $\mathrm{NiO}$ nanoparticles (50 and 100 cycles) and $\mathrm{Al}_{2} \mathrm{O}_{3}$ film $\left(50,100\right.$, and 200 cycles) can be adjusted, obtaining $50 \mathrm{NiO} / \mathrm{Al}_{2} \mathrm{O}_{3} / \mathrm{Pt}, \mathrm{NiO} /$ $100 \mathrm{Al}_{2} \mathrm{O}_{3} / \mathrm{Pt}$, and $\mathrm{NiO} / 200 \mathrm{Al}_{2} \mathrm{O}_{3} / \mathrm{Pt}$. To obtain $\mathrm{CoO}_{x} / \mathrm{Al}_{2} \mathrm{O}_{3} / \mathrm{Pt}, \mathrm{CoO}_{x}$ nanoparticles (35 cycles) were deposited onto $\mathrm{Al}_{2} \mathrm{O}_{3} / \mathrm{Pt}$ by ALD.

Synthesis of $\mathrm{NiO} / \mathrm{Al}_{2} \mathrm{O}_{3}$ and $\mathrm{CoO}_{x} / \mathrm{Al}_{2} \mathrm{O}_{3}$ catalysts. CNCs were first coated with an $\mathrm{Al}_{2} \mathrm{O}_{3}$ layer ( 50 cycles) by ALD and then calcined at $500{ }^{\circ} \mathrm{C}$ for $1 \mathrm{~h}$. Next, $\mathrm{NiO}$ (100 cycles) or $\mathrm{CoO}_{x}$ ( 35 cycles) nanoparticles were deposited by ALD, obtaining a $\mathrm{NiO} / \mathrm{Al}_{2} \mathrm{O}_{3}$ or $\mathrm{CoO}_{x} / \mathrm{Al}_{2} \mathrm{O}_{3}$ catalyst.

Synthesis of $\mathbf{N i O} / \mathrm{TiO}_{2}, \mathrm{TiO}_{2} / \mathrm{Pt}$, and $\mathbf{N i O} / \mathrm{TiO}_{2} / \mathbf{P t}$ catalysts. CNCs were first coated with a $\mathrm{TiO}_{2}$ layer $\left(200\right.$ cycles) by ALD and calcined at $500{ }^{\circ} \mathrm{C}$ for $1 \mathrm{~h}$. Then, $\mathrm{NiO}$ (100 cycles) nanoparticles were deposited by ALD, obtaining a $\mathrm{NiO} / \mathrm{TiO}_{2}$ catalyst. To obtain $\mathrm{TiO}_{2} / \mathrm{Pt}$, Pt nanoparticles $(20$ cycles $)$ and a $\mathrm{TiO}_{2}$ film $(200$ cycles) were deposited onto a CNC template. Then, the $\mathrm{CNC}$ template was removed by calcination at $500{ }^{\circ} \mathrm{C}$ for $1 \mathrm{~h}$, obtaining a $\mathrm{TiO}_{2} / \mathrm{Pt}$ catalyst. $\mathrm{NiO}(100$ cycles) nanoparticles were deposited onto $\mathrm{TiO}_{2} / \mathrm{Pt}$, producing $\mathrm{NiO} / \mathrm{TiO}_{2} / \mathrm{Pt}$.

Sample characterization. The chemical compositions of these samples were determined by ICP-AES. The TEM and HRTEM images were taken on a JEOL$2100 \mathrm{~F}$ microscope. The $\mathrm{N}_{2}$ sorption measurements were performed using 

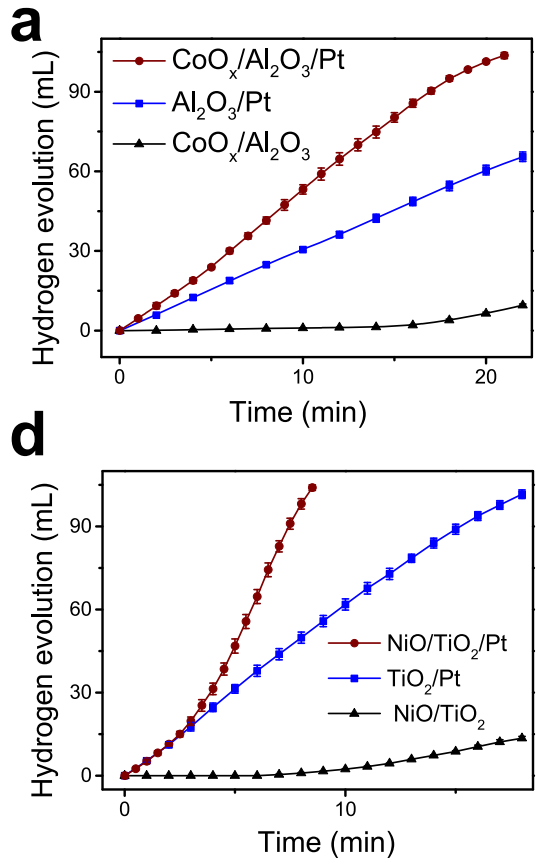

b

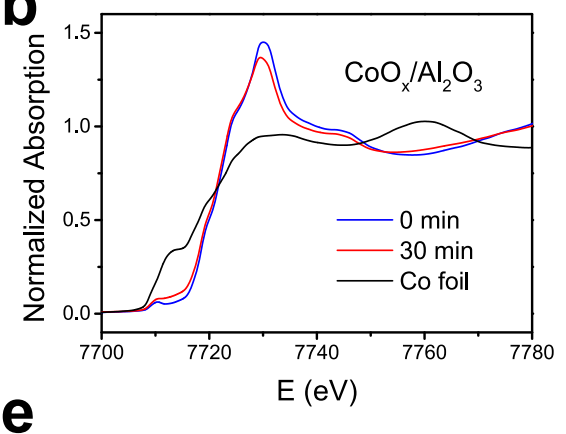

e

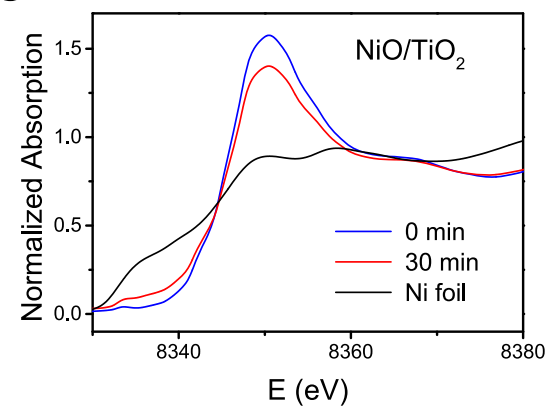

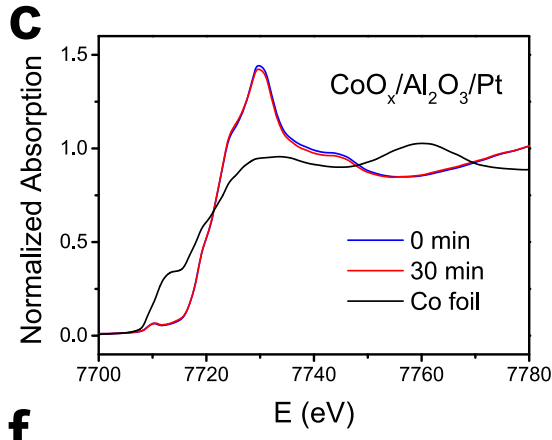

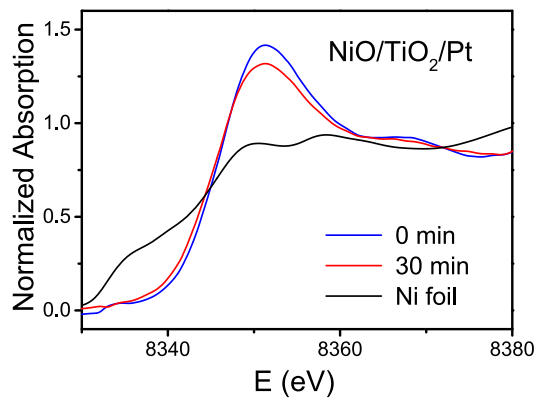

Fig. 4 Reverse spillover effects in $\mathbf{A B}$ hydrolysis catalyzed by the $\mathbf{C o O}_{\mathbf{x}} / \mathbf{A l}_{\mathbf{2}} \mathbf{O}_{\mathbf{3}} / \mathbf{P t}$ and $\mathbf{N i O} / \mathrm{TiO}_{\mathbf{2}} / \mathbf{P t}$ catalysts. a $\mathrm{Volume}$ of $\mathrm{H}_{2}$ generated from $\mathrm{AB}$ solution at $25^{\circ} \mathrm{C}$ catalyzed by $\mathrm{CoO}_{x} / \mathrm{Al}_{2} \mathrm{O}_{3}, \mathrm{Al}_{2} \mathrm{O}_{3} / \mathrm{Pt}$, and $\mathrm{CoO}_{x} / \mathrm{Al}_{2} \mathrm{O}_{3} / \mathrm{Pt}$. In situ Co K-edge XANES spectra for $\mathbf{b} \mathrm{CoO}_{x} / \mathrm{Al}_{2} \mathrm{O}_{3}$ and $\mathbf{c} \mathrm{CoO}_{x} / \mathrm{Al}_{2} \mathrm{O}_{3} / \mathrm{Pt}$ catalysts before reaction and after reaction for $30 \mathrm{~min}$ and the spectrum for Co foil. $\mathbf{d}$ Volume of $\mathrm{H}_{2}$ generated from $\mathrm{AB}$ solution at $25^{\circ} \mathrm{C}$ catalyzed by NiO/ $\mathrm{TiO}_{2}, \mathrm{TiO}_{2} / \mathrm{Pt}$, and $\mathrm{NiO} / \mathrm{TiO}_{2} / \mathrm{Pt}$. In situ Ni K-edge XANES spectra for e $\mathrm{NiO} / \mathrm{TiO}_{2}$ and $\mathbf{f} \mathrm{NiO} / \mathrm{TiO}_{2} / \mathrm{Pt}$ catalysts before reaction and after reaction for $30 \mathrm{~min}$ and the spectrum obtained for $\mathrm{Ni}$ foil. Error bars correspond to the standard deviation for three independent measurements.

Micromeritics Tristar 3000 at $77 \mathrm{~K}$. XRD patterns were collected on a Bruker D8 Advance X-ray diffractometer using a $\mathrm{Cu}$ Ka source. XPS spectra were recorded on an AXIS ULTRA DLD spectrometer (Shimadzu/Kratos) to characterize the surface composition with the Al $\mathrm{Ka}$ line as the excitation source. $\mathrm{H}_{2}$-TPR experiments were performed using a tubular quartz reactor (TP-5080, Tianjin Xianquan, China), into which a $50 \mathrm{mg}$ sample was loaded. The reduction was conducted in a $10 \% \mathrm{H}_{2} / \mathrm{N}_{2}$ atmosphere at a heating rate of $10^{\circ} \mathrm{C} / \mathrm{min}$. Hydrogen consumption was calculated by an external standard method using $\mathrm{H}_{2}$-TPR for $\mathrm{CuO}$ as the standard. The Raman spectra were performed on a LabRam HR Evolution (Horiba, France) spectrometer employing a $\mathrm{He}-\mathrm{Ne}$ laser with an excitation wavelength of $532 \mathrm{~nm}$. After the $\mathrm{AB}$ catalytic hydrolysis reaction for $10 \mathrm{~min}$, the catalysts were centrifuged and dried in a vacuum oven at $30^{\circ} \mathrm{C}$. Finally, the samples were loaded, and the spectra were recorded at room temperature. The in situ XANES for Ni and Co K-edge were obtained on the 1W1B beamline of the Beijing Synchrotron Radiation Facility (BSRF), Institute of High Energy Physics, Chinese Academy of Sciences, and the BL14W1 and BL11B beamlines of the Shanghai Synchrotron Radiation Facility (SSRF), Shanghai Advanced Research Institute, Chinese Academy of Sciences. A Si (111) double-crystal monochromator was used to reduce the harmonic component of the monochrome beam. $\mathrm{Ni}$ and $\mathrm{Co}$ foil, $\mathrm{NiO}, \mathrm{CoO}$, and $\mathrm{Co}_{3} \mathrm{O}_{4}$ were used as reference samples and measured in transmission mode. The sample wafer was placed in the centre of a homemade in situ XANES cell. The spectra for the catalyst were first collected in transmission mode. After that, the AB solution $\left(5 \mathrm{~g} \mathrm{~L}^{-1}\right)$ was fed into the reactor at a speed of $5 \mathrm{~mL} \mathrm{~min}^{-1}$ by a sampling pump. The quick XANES were collected during the reaction at different times. IFEFFIT software was used to calibrate the energy scale, to correct the background signal, and to normalize the intensity. The spectra at the edge jump were simulated by a linear function of the reference $\mathrm{Ni}$ foil and the NiO-based catalyst before the reaction to estimate the proportion of metallic $\mathrm{Ni}^{0}$ in the catalyst during the reaction. The following formula was used:

(in situ XANES $)=f_{1}$. (XANES of Ni foil $)+f_{2} \cdot\left(\right.$ ex situ XANES), where $f_{1}$ and $f_{2}$ are the fractions of the $\mathrm{Ni}$ foil and the as-prepared catalyst before the reaction, respectively.

Catalytic testing. The catalytic performance of the samples was tested for $\mathrm{AB}$ hydrolytic dehydrogenation. Typically, the catalysts were first dispersed in deionized water $(10 \mathrm{~mL})$ placed in a round bottom flask with a magnetic stirrer at $25 \pm 0.5^{\circ} \mathrm{C}$. The reaction was initialized by adding $48 \mathrm{mg}$ of $\mathrm{AB}$ (Aldrich, $97 \%$ ) into the reaction flask under stirring $(700 \mathrm{rpm})$. A gas burette filled with water was connected to the flask to measure the amount of hydrogen evolved during the reaction by monitoring the displacement of the water level. In the $A B$ concentration-dependent study, the reaction was performed at different $A B$ concentrations $\left(75,112.5,150\right.$, and $\left.187.5 \mathrm{mmol} \mathrm{L}^{-1}\right)$ at $25 \pm 0.5^{\circ} \mathrm{C}$. To calculate the activation energy $\left(E_{\mathrm{a}}\right)$, the reaction temperature was varied in the range of $20-35^{\circ} \mathrm{C}$, and the $\mathrm{AB}$ concentration was kept constant at $150 \mathrm{mmol} \mathrm{L}^{-1}$.

Computational method. All DFT calculations were carried out using periodic spin-polarized density functional theory with the Perdew-Burke-Ernzerhof generalized gradient approximation functional ${ }^{51}$ as implemented in the Vienna ab initio simulation package (VASP) ${ }^{52,53}$. The calculations were performed using a plane-wave basis set, with a cut-off kinetic energy of $400 \mathrm{eV}$. Projector-augmentedwave ${ }^{54}$ potentials were used to describe the electron-ion interactions. Dispersion interactions were included by using the DFT-D3 (BJ) correction method of Grimme et al ${ }^{55,56}$. The crystal structure of $\gamma-\mathrm{Al}_{2} \mathrm{O}_{3}$ proposed by Gutiérrez et al. ${ }^{57}$ was adopted in our model system. The most stable (100) surface of $\gamma-\mathrm{Al}_{2} \mathrm{O}_{3}$ with three alumina layers and a $\mathrm{Ni}_{4} \mathrm{O}_{4}$ cluster adsorbed onto it were used for the $\mathrm{NiO} / \gamma$ $\mathrm{Al}_{2} \mathrm{O}_{3}(100)$ slab model. The two bottom layers of the slab were kept fixed. The thickness of the vacuum region was $20 \AA$. A Monkhorst-Pack grid was used for Brillouin-zone integrations with $1 \times 1 \times 1 \mathrm{k}$-mesh (gamma point) sampling. The solvation effect was included with an implicit solvation solvent of water using the VASPsol tool ${ }^{58}$. The free energies at room temperature $(298.15 \mathrm{~K})$ were obtained by adding to the DFT electronic energy $(E)$, the zero-point energy, enthalpy, and entropy contribution from the vibrational modes. The transition states (TS) were calculated using the climbing image nudged elastic band method ${ }^{59}$, and frequency analysis was confirmed to verify the TS.

\section{Data availability}

The data that support the findings of this study are available from the corresponding authors upon reasonable request.

Received: 14 April 2021; Accepted: 3 December 2021; Published online: 10 January 2022

\section{References}

1. Suh, M. P., Park, H. J., Prasad, T. K. \& Lim, D. W. Hydrogen storage in metalorganic frameworks. Chem. Rev. 112, 782-835 (2012).

2. Dresselhaus, M. S. \& Thomas, I. L. Alternative energy technologies. Nature 414, 332-337 (2001). 
3. Sun, Q., Wang, N., Xu, Q. \& Yu, J. Nanopore-supported metal nanocatalysts for efficient hydrogen generation from liquid-phase chemical hydrogen storage materials. Adv. Mater. 32, 2001818 (2020).

4. Schlapbach, L. \& Züttel, A. Hydrogen-storage materials for mobile applications. Nature 414, 353-358 (2001).

5. Chen, W. et al. Mechanistic insight into size-dependent activity and durability in $\mathrm{Pt} / \mathrm{CNT}$ catalyzed hydrolytic dehydrogenation of ammonia borane. J. Am. Chem. Soc. 136, 16736-16739 (2014).

6. Yang, J. et al. Atomic design and fine-tuning of subnanometric Pt catalysts to tame hydrogen generation. ACS Catal. 11, 4146-4156 (2021).

7. Bi, Q. et al. Dehydrogenation of formic acid at room temperature: boosting palladium nanoparticle efficiency by coupling with pyridinic-nitrogen-doped carbon. Angew. Chem. Int. Ed. 55, 11849-11853 (2016).

8. Tedsree, K. et al. Hydrogen production from formic acid decomposition at room temperature using a $\mathrm{Ag}-\mathrm{Pd}$ core-shell nanocatalyst. Nat. Nanotechnol. 6, 302-307 (2011).

9. Wang, N. et al. In situ confinement of ultrasmall Pd clusters within nanosized silicalite-1 zeolite for highly efficient catalysis of hydrogen generation. J. Am. Chem. Soc. 138, 7484-7487 (2016)

10. Liu, Y. et al. Regulating electron-hole separation to promote photocatalytic $\mathrm{H}_{2}$ evolution activity of nanoconfined $\mathrm{Ru} / \mathrm{MXene} / \mathrm{TiO}_{2}$ catalysts. ACS Nano 14, 14181-14189 (2020).

11. Li, W. et al. Exploiting Ru-induced lattice strain in CoRu nanoalloys for robust bifunctional hydrogen production. Angew. Chem. Int. Ed. 60, 3290-3298 (2021).

12. Fu, F. et al. Highly selective and sharp volcano-type synergistic Ni 2 Pt@ZIF-8catalyzed hydrogen evolution from ammonia borane hydrolysis. J. Am. Chem. Soc. 140, 10034-10042 (2018).

13. Karaca, T., Sevim, M. \& Metin, Ö. Facile synthesis of monodisperse copper-platinum alloy nanoparticles and their superb catalysis in the hydrolytic dehydrogenation of ammonia borane and hydrazine borane. ChemCatChem 9, 4185-4190 (2017).

14. Singh, A. K. \& Xu, Q. Synergistic catalysis over bimetallic alloy nanoparticles. ChemCatChem 5, 652-676 (2013).

15. Wang, $\mathrm{S}$. et al. Aqueous solution synthesis of $\mathrm{Pt}-\mathrm{M}(\mathrm{M}=\mathrm{Fe}, \mathrm{Co}, \mathrm{Ni})$ bimetallic nanoparticles and their catalysis for the hydrolytic dehydrogenation of ammonia borane. ACS Appl. Mater. Interfaces 6, 12429-12435 (2014).

16. Li, J. et al. Highly active and stable metal single-atom catalysts achieved by strong electronic metal-support interactions. J. Am. Chem. Soc. 141, 14515-14519 (2019).

17. Chen, W. et al. Synergistic $\mathrm{Pt}-\mathrm{WO}_{3}$ dual active sites to boost hydrogen production from ammonia borane. iScience 23, 100922 (2020).

18. Ren, $\mathrm{X}$. et al. Promoting effect of heterostructured $\mathrm{NiO} / \mathrm{Ni}$ on Pt nanocatalysts toward catalytic hydrolysis of ammonia borane. J. Phys. Chem. Lett. 10, 7374-7382 (2019).

19. Zhang, J. et al. Synergistic effects in atomic-layer-deposited $\mathrm{PtCo}_{x} / \mathrm{CNTs}$ catalysts enhancing hydrolytic dehydrogenation of ammonia borane. Appl. Catal. B: Environ. 235, 256-263 (2018).

20. Ge, Y. et al. PtNi/NiO clusters coated by hollow sillica: novel design for highly efficient hydrogen production from ammonia-borane. ACS Appl. Mater. Interfaces 9, 3749-3756 (2017).

21. Yao, Q., Shi, Y., Zhang, X., Chen, X. \& Lu, Z. Facile synthesis of platinumcerium(IV) oxide hybrids arched on reduced graphene oxide catalyst in reverse micelles with high activity and durability for hydrolysis of ammonia borane. Chem. Asian J. 11, 3251-3257 (2016).

22. Chen, J., Lu, Z., Yao, Q., Feng, G. \& Luo, Y. Complete dehydrogenation of $\mathrm{N}_{2} \mathrm{H}_{4} \mathrm{BH}_{3}$ with $\mathrm{NiM}-\mathrm{Cr}_{2} \mathrm{O}_{3}(\mathrm{M}=\mathrm{Pt}, \mathrm{Rh}$, and Ir) hybrid nanoparticles. $J$. Mater. Chem. A 6, 20746-20752 (2018).

23. $\mathrm{Xu}, \mathrm{D}$. et al. Pt nanoparticles immobilized in mesoporous silica-coated magnetic nanocapsules: a non-leaching catalyst for hydrogen generation from hydrolysis of ammonia borane. Int. J. Hydrog. Energy 42, 27034-27042 (2017).

24. Zhou, Q. \& Xu, C. Nanoporous $\mathrm{PtCo} / \mathrm{Co}_{3} \mathrm{O}_{4}$ composites with high catalytic activities toward hydrolytic dehydrogenation of ammonia borane. J. Colloid Interface Sci. 508, 542-550 (2017).

25. Zhao, B. et al. $\mathrm{Pt}_{\mathrm{x}} \mathrm{Ni}_{10-\mathrm{x}} \mathrm{O}$ nanoparticles supported on $\mathrm{N}$-doped graphene oxide with a synergetic effect for highly efficient hydrolysis of ammonia borane. Catal. Sci. Technol. 7, 5135-5142 (2017).

26. Joo, J. B. et al. Promotion of atomic hydrogen recombination as an alternative to electron trapping for the role of metals in the photocatalytic production of $\mathrm{H}_{2}$. Proc. Natl Acad. Sci. USA 111, 7942-7947 (2014).

27. Roland, U., Braunschweig, T. \& Roessner, F. On the nature of spilt-over hydrogen. J. Mol. Catal. A: Chem. 127, 61-84 (1997).

28. Conner, W. C. \& Falconer, J. L. Spillover in heterogeneous catalysis. Chem. Rev. 95, 759-788 (1995).

29. Prins, R. Hydrogen spillover. Facts and fiction. Chem. Rev. 112, 2714-2738 (2012).

30. Gao, Z. \& Qin, Y. Design and properties of confined nanocatalysts by atomic layer deposition. Acc. Chem. Res. 50, 2309-2316 (2017).
31. Zhang, J. et al. Origin of synergistic effects in bicomponent cobalt oxideplatinum catalysts for selective hydrogenation reaction. Nat. Commun. 10, 4166 (2019)

32. Xiong, M. et al. In situ tuning of electronic structure of catalysts using controllable hydrogen spillover for enhanced selectivity. Nat. Commun. 11, 4773 (2020).

33. Liu, $\mathrm{X}$. et al. Activation of subnanometric $\mathrm{Pt}$ on $\mathrm{Cu}$-modified $\mathrm{CeO}_{2}$ via redoxcoupled atomic layer deposition for CO oxidation. Nat. Commun. 11, 4240 (2020).

34. Lei, Y., Lee, S., Low, K. B., Marshall, C. L. \& Elam, J. W. Combining electronic and geometric effects of $\mathrm{ZnO}$-promoted $\mathrm{Pt}$ nanocatalysts for aqueous phase reforming of 1-propanol. ACS Catal. 6, 3457-3460 (2016).

35. Zhang, H. \& Marshall, C. L. Atomic layer deposition: catalytic preparation and modification technique for the next generation. Chin. J. Catal. 40, 1311-1323 (2019).

36. Marichy, C. \& Pinna, N. Atomic layer deposition to materials for gas sensing applications. Adv. Mater. Interfaces 3, 1600335 (2016).

37. Hu, Q. et al. The precise decoration of Pt nanoparticles with Fe oxide by atomic layer deposition for the selective hydrogenation of cinnamaldehyde. Appl. Catal. B: Environ. 218, 591-599 (2017).

38. Karim, W. et al. Catalyst support effects on hydrogen spillover. Nature 541, 68-71 (2017).

39. Jiang, L. et al. Facet engineering accelerates spillover hydrogenation on highly diluted metal nanocatalysts. Nat. Nanotechnol. 15, 848-853 (2020).

40. Xiong, M., Gao, Z. \& Qin, Y. Spillover in heterogeneous catalysis: new insights and opportunities. ACS Catal. 11, 3159-3172 (2021).

41. Wei, J. et al. In situ Raman monitoring and manipulating of interfacial hydrogen spillover by precise fabrication of $\mathrm{Au} / \mathrm{TiO}_{2} / \mathrm{Pt}$ sandwich structures. Angew. Chem. Int. Ed. 59, 10343-10347 (2020).

42. Kalidindi, S. B., Indirani, M. \& Jagirdar, B. R. First row transition metal ionassisted ammonia-borane hydrolysis for hydrogen generation. Inorg. Chem. 47, 7424-7429 (2008).

43. Yamada, Y., Yano, K., Xu, Q. \& Fukuzumi, S. $\mathrm{Cu} / \mathrm{Co}_{3} \mathrm{O}_{4}$ nanoparticles as catalysts for hydrogen evolution from ammonia borane by hydrolysis. J. Phys. Chem. C. 114, 16456-16462 (2010).

44. $\mathrm{Lu}$, D. et al. A simple and scalable route to synthesize $\mathrm{Co}_{\mathrm{x}} \mathrm{Cu}_{1-\mathrm{x}} \mathrm{Co}_{2} \mathrm{O}_{4}$ $@ \mathrm{Co}_{\mathrm{y}} \mathrm{Cu}_{1-\mathrm{y}} \mathrm{Co}_{2} \mathrm{O}_{4}$ yolk-shell microspheres, a high-performance catalyst to hydrolyze ammonia borane for hydrogen production. Small 15, 1805460 (2019).

45. Hess, N. J. et al. Spectroscopic studies of the phase transition in ammonia borane: Raman spectroscopy of single crystal $\mathrm{NH}_{3} \mathrm{BH}_{3}$ as a function of temperature from 88 to 330 K. J. Chem. Phys. 128, 034508 (2008).

46. Bart, J. C. J. \& Vlaic, G. Extended X-ray absorption fine structure studies in catalysis. Adv. Catal. 35, 1-138 (1987)

47. Shido, T. \& Prins, R. Application of synchrotron radiation to in situ characterization catalysts. Curr. Opin. Solid State Mater. Sci. 3, 330-335 (1998).

48. Zhan, W., Zhu, Q. \& Xu, Q. Dehydrogenation of ammonia borane by metal nanoparticle catalysts. ACS Catal. 6, 6892-6905 (2016).

49. Gudmundsdottir, S., Skulason, E. \& Jonsson, H. Reentrant mechanism for associative desorption: $\mathrm{H}_{2} / \mathrm{Pt}(110)-(1 \times 2)$. Phys. Rev. Lett. 108, 156101 (2012).

50. Yu, C. et al. $\mathrm{H}_{2}$ thermal desorption spectra on $\mathrm{Pt}(111)$ : a density functional theory and kinetic Monte Carlo simulation study. Catalysts 8, 450 (2018).

51. Perdew, J. P., Burke, K. \& Ernzerhof, M. Generalized gradient approximation made simple. Phys. Rev. Lett. 77, 3865-3868 (1996).

52. Hafner, J. Ab-initio simulations of materials using VASP: density-functional theory and beyond. J. Comput. Chem. 29, 2044-2078 (2008).

53. Kresse, G. \& Furthmüller, J. Efficiency of ab-initio total energy calculations for metals and semiconductors using a plane-wave basis set. Comput. Mater. Sci. 6, 15-50 (1996).

54. Csonka, G. I. et al. Assessing the performance of recent density functionals for bulk solids. Phys. Rev. B 79, 155107 (2009).

55. Grimme, S., Antony, J., Ehrlich, S. \& Krieg, H. A consistent and accurate ab initio parametrization of density functional dispersion correction (DFT-D) for the 94 elements H-Pu. J. Chem. Phys. 132, 154104 (2010).

56. Grimme, S., Ehrlich, S. \& Goerigk, L. Effect of the damping function in dispersion corrected density functional theory. J. Comput. Chem. 32, 1456-1465 (2011).

57. Gutiérrez, G., Taga, A. \& Johansson, B. Theoretical structure determination of $\gamma-\mathrm{Al}_{2} \mathrm{O}_{3}$. Phys. Rev. B 65, 012101 (2001).

58. Mathew, K., Sundararaman, R., Letchworth-Weaver, K., Arias, T. A. \& Hennig, R. G. Implicit solvation model for density-functional study of nanocrystal surfaces and reaction pathways. J. Chem. Phys. 140, 084106 (2014).

59. Jónsson, H., Mills, G. \& Jacobsen, K. W. in Nudged Elastic Band Method for Finding Minimum Energy Paths of Transitions 385-404 (World Scientific, 1998). 


\section{Acknowledgements}

We acknowledge the financial support from the National Natural Science Foundation of China (21773282, Z.G.; U1932131, Z.G.; and U1832208, Y.Q.), National Science Fund for Distinguished Young Scholars (21825204, Y.Q.), the National Key R\&D Programme of China (2017YFA0700101, Y.Q.; and 2020YFA0210902, Y.Q.), and Youth Innovation Promotion Association of the Chinese Academy of Sciences (2018208, Z.G.). We are grateful to all staff at the 1W1B beamline of the Beijing Synchrotron Radiation Facility, Institute of High Energy Physics, Chinese Academy of Sciences, and at BL14W1 and BL11B beamlines of the Shanghai Synchrotron Radiation Facility, Shanghai Advanced Research Institute, Chinese Academy of Sciences.

\section{Author contributions}

Z.G. synthesized the catalysts and performed the activity tests. G.W., Z.L., M.X., J.M., and Z.J. helped to perform or provide the XANES measurement. T.L. performed the theoretical calculation. L.W. and S.X. assisted in the synthesis and characterizations of the catalysts. Z.G. and Y.Q. conceived the idea, supervised the work, and wrote the manuscript. All authors contributed to the manuscript.

\section{Competing interests}

The authors declare no competing interests.

\section{Additional information}

Supplementary information The online version contains supplementary material available at https://doi.org/10.1038/s41467-021-27785-5.
Correspondence and requests for materials should be addressed to Zhe Gao or Yong Qin.

Peer review information Nature Communications thanks Niall English and the other, anonymous, reviewer for their contribution to the peer review of this work.

Reprints and permission information is available at http://www.nature.com/reprints

Publisher's note Springer Nature remains neutral with regard to jurisdictional claims in published maps and institutional affiliations.

cc (i) Open Access This article is licensed under a Creative Commons Attribution 4.0 International License, which permits use, sharing, adaptation, distribution and reproduction in any medium or format, as long as you give appropriate credit to the original author(s) and the source, provide a link to the Creative Commons license, and indicate if changes were made. The images or other third party material in this article are included in the article's Creative Commons license, unless indicated otherwise in a credit line to the material. If material is not included in the article's Creative Commons license and your intended use is not permitted by statutory regulation or exceeds the permitted use, you will need to obtain permission directly from the copyright holder. To view a copy of this license, visit http://creativecommons.org/ licenses/by/4.0/.

(C) The Author(s) 2022 